УДК 343.9

DOI https://doi.org/10.51989/NUL.2021.6.28

\title{
БЮРО ЕКОНОМІЧНОЇ БЕЗПЕКИ ЯК СУБ'ЄКТ ЗАБЕЗПЕЧЕННЯ ЕКОНОМІЧНОЇ БЕЗПЕКИ
}

\author{
Стеблянко Аліна Володимирівна, \\ доктор філософії зі спеціальності «Право», \\ асистент кафедри фундаментальної юриспруденції та конституційного права \\ Навчально-наукового інституту права \\ Сумського державного університету
}

\section{Лісов Дмитрій Андрійович,}

студент

Навчально-наукового інститут права

Сумського державного університету

У статті проаналізовано нормативне регулювання діяльності Бюро економічної безпеки України як органу, який здійснюватиме розслідування кримінальних правопорушень у сфері економіки, створення якого передбачене Законом України «Про Бюро економічної безпеки України». Актуальність описаної у статті проблеми пояснюється тим, що належне забезпечення економічної безпеки держави є ключовою умовою розвитку останньої, де правоохоронні органи виступають основними суб'єктами забезпечення економічної безпеки України, а створення Бюро економічної безпеки України безпосередньо спрямоване на підвищення ефективності розслідування злочинів, які посягають на економічну безпеку держави. Водночас метою роботи є аналіз потенційних недоліків у діяльності Бюро економічної безпеки як суб'єкта забезпечення економічної безпеки України із наступним визначенням перспектив його діяльності. Проаналізовано підходи до визначення поняття «економічна безпека держави», а також з'ясовано, що розуміють під забезпеченням національної економічної безпеки України. Зосереджено увагу на завданнях, повноваженнях і функціях, покладених на Бюро економічної безпеки України. Визначено проблемні питання про функціонування досліджуваного органу. Наголошено на перспективах та перевагах діяльності Бюро економічної безпеки України. Проаналізовано досвід зарубіжних країн щодо функціонування органів, які забезпечують економічну безпеку країни, та наголошено, що кожна держава застосовує різні методи для протидії злочинності у сфері економічної безпеки країни. Зроблено висновок, що Бюро економічної безпеки України має стати органом, який поєднає повноваження для розгляду всіх економічних злочинів. Однак невирішеними залишилися деякі проблемні питання, зокрема щодо застосування ризик-орієнтованого підходу і процедури передачі справ іншими органами до Бюро економічної безпеки України. Водночас указаний орган - це нова модель кримінальної розвідки у поєднанні із кримінальним аналізом. За умови його належного функціонування підвищиться рівень довіри до діяльності правоохоронних органів і збільшиться ефективність розслідування економічних злочинів.

Ключові слова: аналітичний орган, економічна безпека, економічні злочини, єдиний правоохоронний орган, ризик-орієнтований підхід.

\section{Steblianko Alina, Lisov Dmytrii. The Bureau of Economic Security as a subject of economic security}

The article analyzes the normative regulation of the Bureau of Economic Security of Ukraine as a body that will investigate criminal offenses in the economic sphere, the creation of which is provided by the Law of Ukraine "On the Bureau of Economic Security of Ukraine". The urgency of the problem described in the article is explained by the fact that proper economic security of the state is a key condition for the development of the latter, where law enforcement agencies are the main actors of economic security of Ukraine, and the creation of the Bureau of Economic Security of Ukraine economic security of the state. At the same time, the purpose of the article is to analyze the potential shortcomings in the activities of the Bureau of Economic Security as a subject of economic security of Ukraine, followed by the definition of prospects for its activities. The approaches to the definition of the concept of economic security of the state are analyzed, 
and it is also clarified what is meant by ensuring the national economic security of Ukraine. The focus is on the tasks, powers and functions assigned to the Bureau of Economic Security of Ukraine. Problematic issues of functioning of the investigated body are determined. Emphasis is placed on the prospects and advantages of the Bureau of Economic Security of Ukraine. The experience of foreign countries on the functioning of bodies that ensure the economic security of the country is analyzed and it is emphasized that each state uses different methods to combat crime in the field of economic security of the country. economic crimes. However, some problematic issues remained unresolved, in particular the application of a risk-based approach and the procedure for transferring cases by other bodies to the Bureau of Economic Security of Ukraine, etc. At the same time, this body is a new model of criminal intelligence combined with criminal analysis. If it functions properly, the level of trust in the activities of law enforcement agencies will increase and the efficiency of the investigation of economic crimes will increase.

Key words: analytical body, economic security, economic crimes, single law enforcement body, risk-oriented approach.

Постановка проблеми. Належне забезпечення економічної безпеки держави $\epsilon$ ключовою умовою розвитку останньої. Досягнення реально помітних показників у цьому напрямі передбачає ефективне і результативне виконання завдань із боку органів, уповноважених на реалізацію функцій держави. Зокрема, саме правоохоронні органи виступають основними суб'єктами забезпечення економічної безпеки України, а створення єдиного правоохоронного органу у сфері забезпечення останньої спрямоване на підвищення ефективності розслідування злочинів, які посягають на економічну безпеку держави. Відповідно, виникає об'єктивна потреба у дослідженні правових засад діяльності Бюро економічної безпеки як новоствореного органу, від функціонування якого залежить рівень злочинності в економічній сфері та створення якого, на переконання В. В. Кареліна, допоможе «уникнути додаткового тиску від численних перевірок органів, що здійснюють контроль за їхньою діяльністю і зловживають своїми повноваженнями» [1, с. 119]. Зазначене вище актуалізує порушену проблематику.

Метою роботи $\epsilon$ аналіз потенційних недоліків у діяльності Бюро економічної безпеки як суб'єкта забезпечення економічної безпеки України із наступним визначенням перспективи його діяльності.

Аналіз останніх досліджень і публікацій. Незважаючи на відносно нещодавнє створення єдиного правоохоронного органу у сфері забезпечення економічної безпеки держави, окремі питання щодо його майбутньої діяльності були предметом дослідження таких науковців, як О. Баба- $\epsilon$ ва, В. Дядик, В. Карелін, К. Кривошеєв, М. Піхоцька, Н. Пузирна та інших.

Виклад основного матеріалу. Перш ніж предметно зосередитися на окресленій тематиці цієї роботи, варто розпочати із характеристики понятійно-категоріального апарату. Зокрема, йдеться про економічну безпеку, яка виступає складовою частиною національної безпеки.

У науковій доктрині існує чимало підходів до визначення поняття «економічна безпека», одне з яких запропоноване 3. Варналієм. Науковець пропонує під економічною безпекою держави розуміти сукупність загальнонаціональних заходів, спрямованих на сталий розвиток і вдосконалення економіки країни, які містять механізм протидії загрозам внутрішнього і зовнішнього характеру, а також ризикам, що супроводжують державу як суб'єкта фінансових відносин [2, с. 103]. У свою чергу, автори монографії «Економічна безпека держави: сутність та напрями формування» зазначають, що економічна безпека держави - це певна сукупність відносин і пов'язаних із ними заходів, які забезпечують здійснення економічного суверенітету, економічне зростання, підвищення добробуту в умовах наявності системи міжнародної економічної взаємозалежності [3, с. 13].

Водночас під забезпеченням національної економічної безпеки України розуміють цілеспрямовану діяльність державних і суспільних інститутів, громадян щодо виявлення та попередження загроз економічній безпеці особи, суспільства і держави, а також протидію цим загрозам як обов'язкову і неодмінну умову захисту національних економічних інтересів 
[4, с. 189]. Саме одним із таких державних інститутів виступає новостворений правоохоронний орган - Бюро економічної безпеки, утворення якого має на меті усунення дублювань у роботі тих правоохоронних органів, до підслідності яких віднесено злочини, що вчиняються у сфері економіки. Зокрема, Служба безпеки України зосереджувала свою діяльність на захисті економіки як складника національної безпеки, підрозділи податкової міліції - на запобіганні порушенням у сфері оподаткування та у бюджетній сфері, Національна поліція - на боротьбі з легалізацією злочинних доходів.

Бюро економічної безпеки України $\epsilon$ центральним органом виконавчої влади, на який покладено завдання із протидії правопорушенням, що посягають на функціонування економіки держави. Відповідно до покладених завдань указаний орган виконує правоохоронну, аналітичну, економічну, інформаційну та інші функції [5]. Із приводу функцій М. Р. Піхоцька зазначає, що виконання правоохоронної функції співробітниками Бюро економічної безпеки полягає у виявленні та розкритті конкретних фінансових злочинів, тоді як аналітична функція охоплює м'які навички, що допомагають виявити і вирішити складні проблеми. Економічна функція Бюро економічної безпеки України, у свою чергу, проявляється у захисті приватної власності, підтримці правопорядку і забезпеченні національної безпеки, спрямуванні податків на чітко визначені цілі, наданні публічних послуг у фінансовому секторі, регулюванні суспільно-економічних галузей суспільного життя, у макроекономічному управлінні, забезпеченні фіскальної і монетарної політики задля контролю ділового циклу [6, с. 121-122].

Натомість аналіз повноважень вищезазначеного органу дозволяє зробити висновок, що навіть таке їхнє широке коло, яке надав йому законодавець, не дозволяє повністю врахувати потреби ефективного забезпечення економічної безпеки держави. Через те варто погодитися з К. О. Кривошеєвим, який у своєму дисертаційному дослідженні, присвяченому діяльності єдиного правоохоронного органу, що забезпечує фінансову безпеку України, пропонує додатково віднести такі повноваження: брати участь у формуванні та реалізації державної політики у сфері протидії економічній злочинності; здійснювати інформаційну взаємодію з усіма правоохоронними органами, органами державної влади та управління; розробляти і затверджувати методику розслідування, кримінального аналізу, аналізу ризиків економічних злочинів; брати участь у розробленні проєктів міжнародних договорів України у сфері запобігання та боротьби із кримінальними правопорушеннями, віднесеними до компетенції цього органу [7, с. 135-136].

Говорячи про проблемні питання функціонування досліджуваного нами органу, які можуть виникнути, передусім варто наголосити на кадровому складі. Нині у нашій країні ми маємо низку правоохоронних органів, де співробітники $\epsilon$ некваліфікованими, унаслідок чого ефективність діяльності органу знижується. Для вирішення цього питання потрібно чітко нормативно врегулювати проходження державної служби у Бюро економічної безпеки України і проходження іспитів для вступу на службу.

Іншим питанням, на яке слід звернути увагу, $\epsilon$ те, що в основу функціонування аналізованого нами органу покладено аналітичний підхід, який не виключає можливості застосування поліцейських заходів під час здійснення діяльності із запобігання, виявлення, припинення і розслідування кримінальних правопорушень, що належать до його підслідності. Зокрема, конкретним прикладом використання аналогічних методів у своїй діяльності $\epsilon$ Фінансова гвардія Італії. Її співробітники за відповідних підстав уповноважені здійснювати слідчі дії, збирати потрібні інформаційні відомості, вживати інших легальних заходів для успішної та ефективної протидії економічним правопорушенням. Тобто функції Фінансової гвардії Італії зводяться до проведення оперативно-розшукової діяльності та досудового розслідування правопорушень, які належать до його підслідності, що відповідає і законодавчо закріпленим функціям Бюро економічної безпеки України [8, с. 507].

Водночас піддається сумніву впровадження ризик-орієнтованого підходу. Як зазначає М. Шевердін, критерії оцінки 
загрози та порядок застосування ризикорієнтованого підходу співробітники новоствореного органу визначатимуть самостійно. Це створює небезпеку того, що потребу у застосуванні будь-якого заходу контролю зацікавлені особи завжди зможуть обґрунтувати штучно завищеним ступенем ризику [9].

Окрім цього, Бюро економічної безпеки України не має повноважень розглядати нетяжкі та середньої тяжкості злочини. Останні віднесені до компетенції Національної поліції України. Очевидно, що створення вказаного Бюро та його нормативна база суперечать своїй ідеї - увібрати в себе всі функції інших органів задля забезпечення економічної безпеки країни.

Окрім того, можуть виникнути складнощі через відсутність чіткої процедури передачі справ іншими органами до Бюро економічної безпеки України, що може мати наслідком виникнення корупційних ризиків і втрату деяких проваджень у кримінальних справах.

Попри це, варто відзначити, що особливістю створення і діяльності зазначеного органу $\epsilon$ не тільки здійснення останнім досудового розслідування кримінальних проваджень виключної підслідності, але і запровадження нової моделі кримінальної розвідки у поєднанні із кримінальним аналізом (аналітикою), базування процесу досудового розслідування на системі Intelligence Led Policing [8, с. 505].

Окрім того, Бюро економічної безпеки стане єдиним органом державної влади, відповідальним за боротьбу з економічними злочинами. Відповідних повноважень позбавляться інші правоохоронні органи, а податкова міліція загалом буде ліквідована. Все це дозволить усунути дублювання правоохоронних і контролюючих функцій, зменшуючи кількість державних органів, які можуть контактувати з бізнесом із питань розслідування економічних і фінансових злочинів [10]. Інакше кажучи, зменшиться тиск на бізнес, що, у свою чергу, дозволить зменшити рівень тіньової економіки.

Аналізуючи міжнародний досвід у сфері забезпечення економічної безпеки, можна зробити висновок, що кожна держава по-різному трактує це поняття і застосо- вує різні методи для протидії злочинності у сфері економічної безпеки країни. Ми розглянемо декілька іноземних органів, які $\epsilon$ прикладом успішного розслідування злочинів у сфері економіки.

Створення спеціальних органів розслідування фінансових злочинів - поширена практика у розвинених країнах. Наприклад, у Сполучених Штатах Америки таку діяльність здійснює окрема секція (FCS) ФБР, Державне агентство із протидії фінансовим злочинам (FinCEN) і Служба внутрішніх доходів (IRS). Ha FCS покладені функції виявлення та запобігання різним видам економічного шахрайства (корпоративного, іпотечного, сировинного та іншого). FinCEN зосереджено на зборі та аналізі відомостей про фінансові транзакції загалом. Мета відомства боротьба із відмиванням коштів та захист фінансової системи держави від злочинного використання. Зона відповідальності IRS - покарання порушників податкового законодавства, а також низка інших злочинів (фіктивне банкрутство, нелегальний гральний бізнес тощо) [11].

Державні органи, призначенням яких $\epsilon$ забезпечення економічної безпеки країни, створені та функціонують і в європейських країнах. Наприклад, у Великій Британії органом економічної безпеки $€$ Управління реалізації фінансових санкцій (Ofifce of Financial Sanctions Implementation) - структура Міністерства економіки та фінансів Великої Британії, до компетенції якої входить роз'яснення, застосування і виконання фінансових санкцій у цій країні [12].

Окремої уваги заслуговує досвід створення єдиного правоохоронного органу у сфері забезпечення економічної безпеки у Казахстані. Департамент економічних розслідувань зазначеної країни $\epsilon$ за своїм адміністративно-правовим статусом правоохоронним органом. Діяльність Департаменту спрямована на захист економічних інтересів держави і бізнесу через попередження, припинення і розслідування податкових і митних правопорушень, а також правопорушень у сфері фінансової діяльності [13].

Можна констатувати, що Україна обрала вірний напрям реформування правоохоронних органів, який узгоджується 
з іноземними практиками. Більше того, обраний шлях у частині створення єдиного правоохоронного органу, до підслідності якого належатимуть усі злочини у сфері економіки, $\epsilon$ важливим кроком у частині адаптації національного законодавства до європейського, враховуючи курс на євроінтеграцію нашої держави.

Висновок. Аналізуючи вищезазначене, варто підсумувати, що Бюро економічної безпеки України має стати органом, який поєднає повноваження для розгляду всіх економічних злочинів. Однак невирішеними залишилися деякі проблемні питання, зокрема щодо застосування ризик-орієнтованого підходу, процедури передачі справ іншими органами до Бюро економічної безпеки України тощо. Водночас указаний орган - це нова модель кримінальної розвідки у поєднанні із кримінальним аналізом. За умови його належного функціонування підвищиться рівень довіри до діяльності правоохоронних органів і збільшиться ефективність розслідування економічних злочинів.

\section{ЛITEPATУPA:}

1. Карелін В. В. Щодо компетенції Бюро економічної безпеки України як суб'єкта запобігання кримінальним правопорушенням у сфері економічної діяльності. Актуальні проблеми вітчизняної юриспруденції. 2021. № 1. С. 116-119.

2. Варналій 3. С., Буркальцева Д. Д., Наєнко О. С. Економічна безпека України: проблеми та пріоритети зміцнення : монографія / За заг. ред. проф. 3. С. Варналія. Київ : Знання України, 2011. 299 с.

3. Шевченко Л.С., Гриценко О.А., Макуха С.М. та ін. Економічна безпека держави: сутність та напрями формування : монографія / За ред. Л. С. Шевченко. Харків : Право, 2009. 312 c.

4. Лекарь С. Правове регулювання економічної безпеки в Україні. Підприємництво, господарство і право. 2019. № 12. С. 186-191.

5. Про Бюро економічної безпеки: Закон України від 09.10.2021 р. № 1774-IX. Відомості Верховної Ради України. 2021. № 23. Ст.197.

6. Піхоцька М. Р. Бюро економічної безпеки як новітній суб'єкт державного фінансового контролю. Економічний вісник. Серія: фінанси, облік, оподаткування. 2021. Вип. 7. С. 117-125.

7. Кривошеєв К. О. Адміністративно-правові засади діяльності єдиного правоохоронного органу, що забезпечує фінансову безпеку України : дис. ... д-ра філософії : 081. Право. Суми, 2021. 233 с.

8. Бабаєва О. В., Дядик В. О. Бюро економічної безпеки в системі органів кримінальної юстиції. Юридичний науковий електронний журнал. 2021. № 4. С. 505-506.

9. Швередін М. Бюро економічної безпеки: чи справдяться очікування бізнесу? Інтерфакс-Україна. 2021. URL: https://bit.ly/3oaFT4m.

10. Аналітика у правоохоронній діяльності: які переваги вона надасть БЕБ? Офіційно про податки. 2021. URL: https://bit.ly/3DeprVb.

11. Снігар М. Бюро економічної безпеки України: черговий (не) залежний орган досудового розслідування? 2021. URL: https://uba.ua/ukr/news/8564/.

12. Пузирна Н. С. Правові аспекти створення та діяльності Бюро економічної безпеки України. Juris Europensis Scientia. 2021. Вип. 21. С. 80-83.

13. О правоохранительной службе : Закон Республики Казахстан от 6 января 2011 г. № 380-IV. URL: https://bit.ly/3xKcEc8. 